\title{
Intangible assets as "nucleus" of process innovation
}

\author{
Alexandru MARIN \\ University POLITEHNICA from Bucharest, Bucharest, Romania \\ alexandru.marin@upb.ro \\ Laura BOANȚĂ \\ University POLITEHNICA from Bucharest, Bucharest, Romania \\ laura.boanta@upb.ro
}

\begin{abstract}
The present paper adds practical experience to the current IP literature and shows a case study upon a start-up company from Romania benefits of its intangible assets in increasing its competitiveness performances, showing how technology-focused SMEs can use IP effectively to support their business models. So, we provide practical means for understanding one practical way in which an innovative SME profits from patents and standards for creating value, also revealing a good practice in IP strategy and management (awareness and involvement at senior management level, pragmatic and innovative use of the flexibility offered by IP) and facilitating the transfer of knowledge of one IP strategy and management associated to a real innovative business example.
\end{abstract}

Keywords: IP Strategy \& Management, Innovative SME, Patent - Standard Strategy (PSS), FRAND terms.

\section{Introduction}

Small and medium-sized companies (SMEs) are essential actors of the European innovative economy, the 23 million SMEs meaning about 98\% of all businesses and offering $80 \%$ private jobs of total working population. There are hundreds of thousands of SMEs from high-tech and fast growing industries, in which patents play an important role (Bereuter et al., 2017).

In 2016, 28\% of all patent applications filed with the European Patent Office (EPO) came from SMEs as important drivers of European innovation orientation. The Intellectual Property SME Scoreboard 2016 study conducted by the EUIPO shows that most of the SMEs consider themselves to be innovative, even if only nine percent of European SMEs register IP rights ("Intellectual Property SME Scoreboard", 2016).

Also, the Intellectual Property SME Scoreboard 2016 indicates that many SMEs do not incorporate currently IP protection into their business strategy. Their ability to use IP as their strategic advantage are far below that of larger companies, being important to make them aware that IP can be a major contributor to their business success.

\section{Literature review}

An open approach to innovation has been largely accepted as a potential source of competitive advantage, benefiting from the use of external sources of innovation and sometimes even implementing external commercialization strategies (Granstrand, 1982; Granstrand \& Sjolander, 1990; Chesbrough, 2003; Chesbrough et al., 2006; Dahlander \& Gann, 2010; West \& Bogers, 2014; Cassiman \& Valentini, 2016). A classical approach, implies that every open innovation activity involves two or more actors, and a firm that engages in open innovation is part of a system of interconnected innovation actors, 
resources, activities, and institutions, connected by organizational and market relations, denoted such an innovation ecosystem. In a broader sense, the systemic nature of open innovation is revealed in every technology oriented activity, especially when discussing about innovative start-up companies, as members of clusters or other associative structures (Chesbrough \& Bogers, 2014; West et al., 2014; Bogers et al., 2017).

When innovation is exercised by several SMEs, rather than in big companies, is important for innovators to establish positions in complementary assets, i.e. when imitation is easy (Teece, 2006). However, complementary technologies don't receive yet much explicit attention and the role of intellectual property (IP) strategy is not sufficiently exploited, as an important asset for firms' competitiveness (Granstrand, 1999; Pisano, 2006; Teece, 2006; Pisano \& Teece, 2007; Somaya, 2012). Also, innovation often takes place in complex multi-technology systems with complementary innovations spread across actors (Granstrand et al., 1997; Hall \& Ziedonis, 2001; Bessen, 2004; Teece, 2009; Somaya et al., 2011; Granstrand \& Holgersson, 2013). In such settings, IP strategy impacts appropriability both directly, through improved and protected sales and margins, and indirectly, for example through cross-licensing agreements, improved negotiation positions, standard setting, blocking of others' R\&D, and improved provision of complementary innovations (Arundel et al., 1995; Duguet \& Kabla, 1998; Granstrand, 1999; Bekkers et al., 2002a; Baldwin \& von Hippel, 2011; Holgersson \& Wallin, 2017). Moreover, a specific firm's freedom to operate, i.e. the ability to do business without being excluded by the IP rights (IPRs) of others, is impacted by the firm's own IP strategy (Granstrand, 1999; Lemley \& Shapiro, 2007; Bessen \& Maskin, 2009; Somaya et al., 2011; Holgersson \& Wallin, 2017).

Standardization is the process of developing and implementing specifications based on the consensus of the views of firms, users, interest groups and governments (Sherif, 2006; Saltzman et al., 2008). The resulting standards are intended to promote compatibility, interoperability and quality. When a firm pursues a standard to produce an innovation outcome, this is what we call a "standardization effort".

Standardization has a significant impact on the creation and diffusion of innovations (Xie et al., 2016). However, prior research on the relationship between standardization and innovation remains inconsistent. Some studies have proposed a positive relationship, where standardization fosters the diffusion of innovation and changes industrial structures, whereas others have argued that it constrains innovation, by inhibiting creativity and postponing the gestation period between invention and successful commercialization. In specific cases, standardization can establish managerial control when implementing innovation in a manufacturing context, but it might also constrain the producer-client relationship in a service context.

Modern knowledge-based economies increasingly rely on standards upon which innovative products are built (Tsilikas \& Tapia, 2017). Standards allow businesses to benefit from economies of scale, to specialize in what they do best and invest in product differentiation. Standards reduces barriers for trade, create open markets and a level playing field, thus spurring competition and innovation. Consumers also reap substantial benefits from standardization, in terms of lower prices, wider and interoperable product variety and more innovation. Standards can be arrived at either through unmediated market competition processes as de facto standards, or through industry coordination within standards-development organizations (SDOs.). 
In a consensus-driven process, SDOs select the best technologies amongst technical contributions resulting from substantial R\&D investment, with a view to solving complex technical problems raised in standards development (Tsilikas \& Tapia, 2017). Although open and accessible to all interested parties to implement, standards often comprise proprietary technologies contributed by technology sponsors.

Standard-essential patents (SEPs) enable innovators and contributors to benefit from positive externalities from standardization and earn a fair return on their investment in R\&D (Tsilikas \& Tapia, 2017). Standardization has facilitated the emergence and growth of a vibrant and open innovation marketplace, bringing together contributors of cuttingedge technologies and suppliers of innovative consumer products and services. This has only been possible thanks to the commitment of contributors to make their technology essential to the standard accessible on "Fair, Reasonable and Non-Discriminatory" (FRAND) terms and conditions. But SMEs' involvement in standardization fails to reflect their paramount importance for jobs and growth; SMEs lag behind bigger companies in standardization. A major reason for SMEs' secondary role in collaborative standardization is technological complexity and the scale of investment needed to develop a competitive technological platform.

At the same time, standardization offers an open ecosystem within which SMEs can successfully contribute with their innovative technologies, largely due to SDOs' high due process standards that many proprietary ecosystems fail to observe (Gallini, 2014). Nonetheless, once their technology is selected to become part of a standard, SMEs depend on effective intellectual property protection in order to earn a return on their R\&D investment. So, SMEs can enhance their competitiveness and reputation not only by contributing but also by implementing formal standards in their products. However, SMEs which are purely implementers are said to often lack the skills necessary to identify the key players in the field, and the reasonable compensation for the technology they are using, and do not know how to react to licensors that fail to offer FRAND terms.

The present paper is intended to add practical experience to the current IP literature. There are no sufficient examples showing how technology-focused SMEs can use IP effectively to support their business models. So, this case study is destined to provide an understanding of one practical way in which an innovative SME profits from patents and standards for creating value, also revealing a good practice in IP strategy and management (awareness and involvement at senior management level, pragmatic and innovative use of the flexibility offered by IP) and facilitating the transfer of knowledge of one IP strategy and management associated to a concrete business example.

\section{Methodology}

The methodology used for developing the present case study viewed the following objectives:

- Provide an understanding of what are the ways in which SMEs can profit from patents and create value, i.e. protect key products, facilitate funding, developing a standard based on their patentable inventions;

- Define and communicate good practices in IP strategy and management, i.e. awareness and involvement at senior management level, early capture of IP, timely involvement of IP experts, pragmatic and innovative use of the flexibility offered by IP; 
- Facilitate the transfer of knowledge of IP strategy and management by presenting concrete business examples.

By running several interviews with top management of an SME, acting like a technology based innovative start-up, by using standard topics from innovation audits, we followed the scope of emphasizing how the role of IP changes as a company moves through the different stages in its commercial life, depending strongly on the company's business model, the IP ecosystem where it operates in and the market mechanisms at play.

All chapters of our study leaded to a specific methodological outcome, referring to the strategic role of IP rights, i.e. to bring more to SMEs than merely a costly insurance against imitation. The essential question was: are IP rights only useful to protect the products and support the freedom to operate, or also destined to increase the value and improve the image of the company and its products?

Another important question addressed the influence of activity time experience on the role of patents or other IP rights, in tight connection with evolving the IP strategy and management of the company, when targeting to pass from a start-up to a more mature enterprise. Is a strong patent portfolio, for example, an important support for companies to diversify their business model and generate revenues not only from direct product sales, but also from technology licensing? These discussable hypotheses are in a broad agreement with the Intellectual Property SME Scoreboard 2016 study, which looked at why SMEs in the European Union use IP rights.

Finally, the present case study shed light on the specific challenges faced by our SME subject for study (PROCESS INNOVATION NUCLEUS Ltd., named onwards PIN) in the current European patent system. Taking into account future developments, we made an inquiry about the expected benefits of the forthcoming Unitary Patent package for SMEs. The arguments to be brought in our discussion were connected to savings in time and money, as well as to an increased legal certainty across the EU market, as a simpler alternative to the existing system.

\section{Results and discussions}

As mentioned in the previous paragraph, PIN ("Homepage", accessed in February 2018) is an innovative start-up from Romania which focuses on treatment, recycling and recovery of metals and nonmetals from various wastes - i.e. medical waste, electronic scrap, various industrial process residues and mine tailings). While having a strong IP strategy, the company aims at growing alongside its innovations and has a business model focused on delivering both disruptive and incremental solutions.

PIN was founded in 2014 by four shareholders (three Romanians and one Latvian) actively involved in all innovation projects. PIN's vision is to develop new technologies and products in open innovation partnerships. As such, PIN was set up to be a research and commercial vehicle for innovative solutions created by its shareholders and other stakeholders and designed to be environmentally friendly, energy efficient, cost effective and highly productive when comparing with existing technologies. PIN considers innovation as one of its greatest values while placing it at the foundation of each endeavor. Through leadership, collaboration, integrity, high standards and performance PIN strives to excel by bringing progress beyond the state of the art and by putting into place an 
environment able to facilitate the market uptake of both incremental and disruptive innovations.

In order to facilitate the innovation process, PIN has developed a strong research group within and outside the company, comprising of experienced researchers and innovation experts. Furthermore, PIN is a member of Măgurele High Tech Cluster (MHTC, accessed February 2018) starting from November 2014. MHTC represents a cross-industry innovation cluster having the main mission of exploiting the scientific research results generated by the European Scientific Infrastructure: Extreme Light Infrastructure - Nuclear Physics (ELI-NP, accessed February 2018). As cluster member, PIN seeks to establish strategic partnerships with other cluster members, bringing forward its new ideas as leverage for research and innovation partnership agreements.

With the help of its research group, PIN has undertaken the market uptake of several patented technologies, whose co-owners and co-inventors are PIN shareholders.

\section{First case study: Sterilize equipment}

After less than three years from its funding, PIN has fully developed and homologated a patented technology and equipment for sterilizing medical waste by multi-action treatment using microwave field, ultraviolet light and ozone ("PINucleus 1.0", accessed February 2018). The solution represents an environmentally friendly and efficient process with high productivity results. All actions, including shredding of waste take place in one single reactor type equipment. After successfully developing a TRL 9 prototype for sterilizing medical waste at the highest Sterility Assurance Level (SAL) of "6-log reduction" (10-6) required for sterilization procedures by the European legislation, PIN is now selling the resulted equipment on the market.

Having initially targeted the Romanian market, PIN and the other co-owners (i.e. its shareholders) filled the patent locally thus obtaining patent protection for the Romanian jurisdiction. Aldo the IP strategy in this case was to claim the priority date and to file for patent in other European jurisdictions, this was unfortunately not done in due time and the opportunity for extending the protection in other European jurisdictions was lost.

In order to compensate the shortcomings, PIN has adopted and developed a strategic instrument called Patent - Standard Strategy (PSS). The goal is to elaborate new standards based on patented technologies in collaboration with the National Standardization Body in Romania (ASRO). Combining patents and new standards based on patented technologies allows to effectively benefit from the advantages of both instruments and to compensate the shortcomings of each individual instrument.

Such strategy is already being implemented in relation with the national patent no. 129984/30.03.2016 for "Method and Apparatus for Sterilizing Medical Waste". At PIN's initiative the National Standardization Body in Romania (ASRO) has started a process for the elaboration of a new standard having title: "Sterilization of medical waste Requirements for development, validation and routine control of a low temperature sterilization process of medical waste by multi-action treatment using microwave field, ultraviolet light and ozone". The index of the new standard being elaborated is SR 13573:2016 and the standardization process was expected to be completed by the end of 2017. Furthermore, the European Committee for Standardization (CEN) has confirmed that there is no other European standard similar to the one which is currently undergoing the 
elaboration process, so is clearly possible to extend the mentioned standard at European level.

\section{Second case study: Nano-powders equipment}

Another project developed by PIN starting from a patented technology created by its shareholders aims at putting on the market an environmental friendly equipment for producing nano-powders. For this purpose, PIN requested and it was granted an European financed project and its implementation started in September, 2016 ("Nanoapparatus", accessed February 2018).

The referred nanotechnology benefits from a European patent which was validated in Germany, France and Romania ("EP2790857", accessed February 2018). Both Germany and France are markets with huge potential for nanotechnology based products, while Romania provides a market where PIN would have no local competitors, but a continuously growing demand for nanotechnology products.

\section{Managing IP and Unitary Patent Protection}

PIN considers IP an important value proposition of its business model. Intangible assets are the "nucleus" of its development strategy generating as immediate results a good company image and reputation, increase in product reliability, support in requesting and securing public funding. These aspects are essential for exploiting market opportunities as they arise, while the strategy is to reinvest a large portion of PINs turnover back into their Research - Development - Innovation (RDI) priorities.

IP management is being handled in house, and benefiting also from outside expertise. Separately from day-to-day IP management activities, regular short meetings are organized with an external Key Account Manager for innovation design management issues, focused on analyzing technology progress. NDAs are being concluded with all staff members while promoting a reward policy for IP creation.

PIN's IP was so far created "in-house". Following a new "open innovation" strategy approach, PIN is very much engaged in collaborations with universities and other research organizations in an attempt to "push" the innovations towards the market.

PIN's target is to be active on the European market. Nevertheless, considering that patent protection in all European jurisdictions would be far too expensive, PIN focuses on markets with easily identifiable penetration and growth potential. A not completely full disclosure policy is being used by PIN when filing patent applications and important knowhow is being kept secret in order to ensure a form of protection in jurisdictions where patents are not validated.

In PIN's case, the fragmented patent system in Europe meant limitations and lost value, such as renouncing patent protection in several European jurisdictions. This was the case when renouncing claiming priority and validating in other European jurisdictions the national patent no. 129984/30.03.2016 for "Method and Apparatus for Sterilizing Medical Waste". The complexity of handling multiple jurisdictions represent a limitation in terms of growth strategy (e.g. specific requirements; translating claims in the case of certain jurisdiction can carry very high costs which would not be necessary if Unitary Patent Protection (UPP) becomes available; still the fees of the corresponding patent agents add up to the already high fees of the initially contracted patent agent). Not extending the 
protection of the referred national patent means also exposing an unprotected invention to competitors when penetrating new European markets. Such limitations require thinking outside the box and identifying other strategic instruments to compensate the lack of patent protection in all European jurisdictions of interest, such as Patent - Standard Strategy (PSS).

Once the UPP will enter into force, PIN expects to have direct effects such as providing easier access to information about all patent related matters and procedures within the UPP system, requiring lower costs, allowing for simplifying the decision-making process in terms of foreign applications and national validation, providing better policies to support the market uptake of innovations starting from patented inventions.

\section{Conclusions}

PIN should benefit in the future of synergies of its patents with other forms of IP, as trade secrets and trade marks (e.g. for the "Device for Sterilizing Medical Waste").

PIN scale-up should be accompanied by the increase of its patent families, as number and as quality (strengths of patents) and to prepare for defending them against potential infringement (set aside from profit some money for getting into court, under different jurisdictions, at least in Romania). So, it is crucial for PIN to continue the adequate achievement of IP protection for their technologies. It is important that promising ideas be protected by well-drafted, strong patents that can provide value in subsequent licensing negotiations. Unfortunately, most SMEs lack dedicated employees that could manage inhouse patent development and portfolio building, but PIN understood this and has solved favorably this issue. When contacting external patent lawyers, PIN identified those experienced in the technology field they wished to protect, otherwise being not be able to show infringement of its patent by some products that, if well drafted, its patent could have covered.

PIN understands and will emphasize more the role of external Key Account Manager and Patent Attorney when implementing innovation design management and IP strategy measures. PIN would also need support in the commercialization phase of their technologies, because they lack the experience of larger corporations in complex and resource-draining negotiations, monitoring and enforcement of their IPRs. Since access to private-sector professional services is expensive, it would be advisable to aim for additional financial support.

Undertaking a FRAND commitment, PIN should offer access on FRAND terms. For that, it should establish a mechanism to determine FRAND accurately. Otherwise PIN risks not obtaining an injunction against an infringer from a court. To determine the value that its technology has for the end product, PIN first needs to determine a reasonable cumulative royalty rate, by looking at former declarations made by main contributors of the standardization process, as well as at studies that estimate the cumulative rates by analyzing published declared rates, companies' annual reports and other reliable data (such as information disclosed in court cases and rates published by patent pool).

In the spirit of open innovation, cooperation with universities and research organizations should be more developed, in order to perform early-stage research and acquire new skill-sets at a reasonable cost, by using public funding in partnership projects. 


\section{References}

Arundel, A., van de Paal, G., Soete, L. (1995). Innovation Strategies of Europe's Largest Industrial Firms: Results of the PACE Survey for Information Sources, Public Research, Protection of Innovations and Government Programmes, Maastricht: MERIT.

Baldwin, C.Y., von Hippel, E. (2011). Modeling a paradigm shift: from producer innovation to user and open collaborative innovation, Organ. Sci. 22 (6), 1399-1417.

Bekkers, R., Duysters, G., Verspagen, B. (2002a). Intellectual property rights, strategic technology agreements and market structure: the case of GSM, Res. Policy 31, (7), 1141-1161.

Bereuter, T., Ménière, Y., Rudyk, I. (2017). SME Case Studies on IP Strategy and IP Management - Releasing Untapped Value, les Nouvelles - Journal of the Licensing Executives Society Volume LII, No. 4, Retrieved from https://ssrn.com/abstract=3068763.

Bessen, J. (2004). Holdup and licensing of cumulative innovations with private information, Econ. Lett. 82 (3), 321-326.

Bogers, M., Zobel, A.-K., Afuah, A., Almirall, E., Brunswicker, S., Dahlander, L., Frederiksen, L., Gawer, A., Gruber, M., Haefliger, S., Hagedoorn, J., Hilgers, D.,Laursen, K., Magnusson, M.G., Majchrzak, A., McCarthy, I.P., Moeslein, K.M., Nambisan, S., Piller, F.T., Radziwon, A., Rossi-Lamastra, C., Sims, J., TerWal, A.L.J. (2017). The open innovation research landscape: established perspectives and emerging themes across different levels of analysis, Industry \& Innovation 24 (1), 8-40.

Cassiman, B., Valentini, G. (2016). Open innovation: are inbound and outbound knowledge flows really complementary? Strategic Manag. J. 37 (6),1034-1046.

Chesbrough, H., Bogers, M. (2014). Explicating open innovation: clarifying an emerging paradigm for understanding innovation, In: Chesbrough, H., Vanhaverbeke, W., West, J. (Eds.), New Frontiers in Open Innovation, Oxford University Press, Oxford.

Chesbrough, H.W. (2003). Open Innovation: the New Imperative for Creating and Profiting from Technology, Harvard Business School Press, Boston, MA.

Dahlander, L., Gann, D.M. (2010). How open is innovation?, Res. Policy 39 (6), 699-709.

Duguet, E., Kabla, I. (1998). Appropriation strategy and the motivations to use the patent system: an econometric analysis at the firm level in French manufacturing, Ann.

Econ. Statistics/Ann. d'Economie de Statistique (49/50), 289-327.

ELI-NP (2018). Retrieved from http://www.eli-np.ro/index.php.

EP2790857 (2018). Retrieved from https://register.epo.org/application?number=EP12704244\&lng=en\&tab=doclist.

EUIPO (2016). Intellectual Property SME Scoreboard, Retrieved from https://euipo.europa.eu/ohimportal/en/web/observatory/sme-scoreboard-2016.

Gallini, N. (2014). Cooperating with competitors: Patent pooling and choice of a new standard, International Journal of Industrial Organization 36, 4-21.

Granstrand, 0. (1982). Technology, Management and Markets: an Investigation of R\&D and Innovation in Industrial Organizations. Frances Pinter, London.

Granstrand, O., Sjolander, S. (1990). Managing innovation in multi-technology corporations, Res. Policy 19 (1), 35-60. 
Granstrand, O., Patel, P., Pavitt, K. (1997). Multi-technology corporations: why they have 'distributed' rather than 'distinctive core' competences, Calif. Manag. Rev. 39 (4), 825.

Granstrand, O. (1999). The Economics and Management of Intellectual Property: towards Intellectual Capitalism, Edward Elgar Publishing, Cheltenham.

Granstrand, O., Holgersson, M. (2013). Managing the intellectual property disassembly problem, Calif. Manag. Rev. 55 (4), 184-210.

Hall, B.H., Ziedonis, R.H. (2001). The patent paradox revisited: an empirical study of patenting in the U.S. semiconductor industry, 1979-1995, RAND J. Econ. 32 (1), 101128.

Holgersson, M., Wallin, M.W. (2017). The patent management trichotomy: patenting, publishing, and secrecy, Manag. Decis. 55 (6), 1087-1099.

Homepage PIN (2018). Retrieved from https://pincompany.weebly.com/.

MHTC (2018). Retrieved from http://www.mhtc.ro/en/.

Nanoapparatus (2018). Retrived from http://nanoapparatus.ro/.

PINucleus 1.0 (2018), Retrieved from https://www.youtube.com/watch?v=Ru-sUSscr34.

Pisano, G. (2006). Profiting from innovation and the intellectual property revolution, Res. Policy 35 (8), 1122-1130.

Pisano, G.P., Teece, D.J. (2007). How to capture value from innovation: shaping intellectual property and industry architecture, Calif. Manag. Rev. 50 (1), 278-296.

Saltzman, J., Chatterjee, S., Raman, M. (2008). A framework for ICT standards creation: the case of ITU-T standard H.350, Info. Syst., 33, pp. 285-299.

Sherif, M.H. (2006). Standards for telecommunications services, In: Jakobs, K. (Ed.), Advanced Topics in Information Technology Standards and Standardization Research, Idea Group Publishing, Hershey, PA, 183-205.

Somaya, D. (2012). Patent strategy and management, J. Manag. 38 (4), 1084-1114.

Somaya, D., Teece, D.J.,Wakeman, S. (2011). Innovation in multi-invention contexts: mapping solutions to technological and intellectual property complexity, Calif. Manag. Rev. 53 (4), 47-79.

Teece, D.J. (2006). Reflections on 'profiting from innovation'. Res. Policy 35 (8), 1131-1146.

Teece, D.J. (2009). Dynamic Capabilities \& Strategic Management: Organizing for Innovation and Growth, Oxford University Press, Oxford.

Tsilikas, H., Tapia, C. (2017). SMEs And Standard Essential Patents: Licensing Efficiently In The Internet Of Things, les Nouvelles - Journal of the Licensing Executives Society, Volume LII No. 4, Retrieved from https://ssrn.com/abstract=3009039.

West, J., Bogers, M. (2014). Leveraging external sources of innovation: a review of research on open innovation, J. Prod. Innovation Manag. 31 (4), 814-831.

West, J., Salter, A., Vanhaverbeke, W., Chesbrough, H. (2014). Open innovation: the next decade, Res. Policy 43 (5), 805-811.

Xie, Z., Hall, J., McCarthy, I.P., Skitmore, M., Shena, L. (2016). Standardization efforts: The relationship between knowledge dimensions, search processes and innovation outcomes, Technovation, 48-49, 69-78. 